\title{
Variasi Pemberian Bioton terhadap Kelimpahan Moina sp.
}

\section{(Variations in Biotons on the Abundance of Moina sp.)}

\author{
Anny Rimalia*) \& Yulius Kisworo \\ Program Studi Budidaya Perairan Fakultas Pertanian Universitas Achmad Yani Banjarmasin \\ *annyrimalia.uvaya@gmail.com
}

\begin{abstract}
ABSTRAK
Ikan setelah fase absorsi kantong telur membutuhkan pemberian makanan dari luar, berupa organisme makanan alami yang segar, seperti phytoplankton, zooplankton ataupun larva serangga air, Organisme makanan alami ini jumlahnya terbatas. Usaha produksi massal pakan alami masih terbatas pada beberapa jenis yang berasal dari perairan laut atau payau. Untuk jenis pakan ikan alami air tawar masih terbatas hanya untuk bahan uji coba. Penelitian ini bertujuan untuk mengetahui dosis terbaik pupuk cair Bioton yang ditambahkan ke dalam media pemeliharaan terhadap laju tingkat kelimpahan populasi Moina sp. Penelitian dilaksanakan di Laboraturium Basah Prodi Budidaya Perikanan Fakultas Pertanian Universitas Ahmad Yani Banjarmasin pada Bulan Maret - April 2020 Metode yang digunakan dalam penelitian ini adalah eksperimen dengan Rancangan Acak Lengkap 4 perlakuan dan 3 ulangan. Perlakuan yang diterapkan sebanyak 4 perlakuan dengan 3 kali ulangan, dengan perlakuan pemberian dosis pupuk cair Bioton sebagai berikut : $A=5 \mathrm{ml} / 3 \mathrm{l}$ air, $B=10 \mathrm{ml} / 3 \mathrm{l}$ air, $C=15 \mathrm{ml} / 3$ l air, dan D = tanpa pupuk cair Bioton (kontrol). Hasil penelitian didapat kelimpahan Moina sp pada perlakuan $A=4.333 \mathrm{ind} / \mathrm{l}, B=3.633 \mathrm{ind} / \mathrm{l}, C=2.700 \mathrm{ind} / \mathrm{l}$ dan $D=3.034 \mathrm{ind} / \mathrm{l}$. Hasil uji anova semua perlakuan berbeda sangat nyata, maka terima $H_{1}$ yaitu pemberian bioton dengan dosis yang berbeda berpengaruh nyata terhadap kelimpahan Moina sp. Hasil Uji BNT semua perlakuan memiliki perbedaan tingkat kelimpahan yang sangat nyata, kecuali perlakuan D terhadap perlakuan $C$ yang berbeda nyata, dengan perlakuan terbaik adalah dosis pupuk cair bioton $5 \mathrm{ml} / 3$ l air (perlakuan A).
\end{abstract}

Kata Kunci : Bioton, Moina sp., dosis, kelimpahan.

\section{ABSTRACT}

Fish after the egg-bag absorption phase require external feeding, in the form of fresh natural food organisms, such as phytoplankton, zooplankton, or aquatic insect larvae. These natural food organisms are limited in number. The business of mass production of natural food is still limited to several types originating from marine or brackish waters. For this type of natural freshwater fish feed, it is still limited to experimental materials. This study aims to determine the best dosage of Bioton liquid fertilizer added to the maintenance medium to the rate of population abundance of Moina sp. The research was conducted at the Wet Laboratory of Fisheries Cultivation Study Program, Faculty of Agriculture, Ahmad Yani University, Banjarmasin. The method used in this study was an experiment with a completely randomized design of 4 treatments and 3 replications. The treatment applied was 4 treatments with 3 repetitions, with the following treatment of Bioton liquid fertilizer: $A=5 \mathrm{ml} / 3 \mathrm{l}$ water, $B=10 \mathrm{ml} / 3 \mathrm{l}$ water, $C=15 \mathrm{ml} / 3 \mathrm{l}$ water, and $D=$ without Bioton liquid fertilizer (control). The results showed that the abundance of Moina sp in treatment $A=4,333 \mathrm{ind} / l, B=3,633 \mathrm{ind} / l, C$ $=2,700 \mathrm{ind} / \mathrm{l}$ and $\mathrm{D}=3,034 \mathrm{ind} / \mathrm{l}$. The ANOVA test results of all treatments were very significantly different, so accept H1, namely giving bioton with different doses had a significant effect on the abundance of Moina sp. The results of the LSD test of all treatments had a very significant difference in abundance, except for treatment $D$ to treatment $C$ which was significantly different, with the best treatment being a dose of $5 \mathrm{ml} / 3$ lof water (treatment A).

Keywords: Bioton, Moina sp., dosage, abundance.

Article History Submitted: September 17, 2020 Approved with minor revision: Accepted: November 27, 2020 Published: December 29, 2020 


\section{PENDAHULUAN}

Perkembangan penduduk di tanah air kita semakin meningkat, sehingga kebutuhan akan gizi (protein hewan) juga semakin bertambah. Berbagai usaha untuk memenuhi kebutuhan meningkatkan protein hewani telah dilakukan. salah satu cara yang dapat dilakukan untuk pemenuhan Gizi tersebut adalah dengan mengembangkan usaha budidaya ikan (Asriani, et. al., 2018).

Agar budidaya ikan dapat berjalan dengan lancar, salah satu kunci utamanya adalah dengan menyediakan makanannya dalam jumlah yang kuntinyu. Menurut Aggraeni \& Abdulgani (2013), jenis makanan yang dapat diberikan pada ikan yaitu terdiri dari dua jenis makanan alami dan makanan buatan. Makanan alami adalah organisme yang hidup bersamasama dengan spesies ikan yang dipelihara atau dipelihara secara terpisah dalam unit produksi yang merupakan komposisi dari spesifik ataupun dikumpulkan dari alam. Makanan buatan merupakan komposisi dari berbagai bahan yang dicampur menurut keperluan untuk diberikan kepada ikan sebagai sumber energi.

Hampir semua jenis ikan, baik laut maupun ikan air tawar yang dipelihara setelah fase absorsi kantong telur membutuhkan fase pendahuluan pemberian makanan dari luar, berupa organisme makanan alami yang segar, seperti phytoplankton, zooplankton ataupun larva serangga air. Namun terkadang makan alami yang sangat diperlukan tersebut tidak tersedia dalam jumlah yang cukup. Akibatnya tingkat kematian burayak pada fase ini relatif tinggi. Untuk menjaga ketersediaan makanan alami perlu dilakukan pembudidayaan dengan kualitas dan kuantitas yang optimal (Husma, 2017).

Beberapa jenis pakan alami yang biasa diproduksi secara massal adalah infusoria, Rotitera, Kutu Air, Diatome, Cholera, Artemia dan Cacing Tubifex. Namun usaha produksi massal masih terbatas pada beberapa jenis, terutama yang bearasal; dari perairan laut atau payau. Untuk jenis pakan ikan alami yang berasal dari perairan tawar masih terbatas pada penggunaannya, terutama hanya untuk bahan uji coba. Padahal hampir semua pakan ikan alami tersebut memiliki prosfek yang cukup baik untuk masa mendatang (Husma, 2017)

Pakan alami ini dapat diproduksi secara massal pada lingkungan yang terkendali dan memiliki daya penyesuaian diri (toleransi) yang tinggi terhadap perubahan lingkungan. Pakan ikan ini juga memiliki nilai gizi yang cukup tinggi dan memberikan pengaruh terhadap hasil panen ikan. Jenis makanan alami yang diberikan, harus disesuaikan dengan tingkat umur yang berhubungan dengan ukuran ikan dan bukaan mulut (Agus, et. al., 2010).

Untuk mendapatkan produktifitas makanan alami diperlukan unsur hara yang lengkap dan dukungan kualitas air yang optimum, sehingga adanya penambahan unsur hara pada perkolaman /pertambakan akan mempengaruhi komposisi makanan alami (Chilmawati, 2008).

Penelitian ini bertujuan untuk mengetahui dosis terbaik pupuk cair Bioton yang ditambahkan ke dalam media pemeliharaan terhadap laju tingkat kelimpahan populasi Moina sp.

\section{METODE PENELITIAN}

Penelitian ini dilaksanakan di Lab. Basah Prodi Budidaya Perairan Fakultas Pertanian Universitas Achmad Yani Banjarmasin. Alat yang digunakan dalam penelitian ini adalah 1) Baskom plastik dengan ukuran diameter $30 \mathrm{~cm}$ sebanyak 12 (dua belas buah). 2)Aerasi beserta kelengkapannya. 3)Serok. 4) Gelas ukur. 5) Pipet. 6) Kain strimen. 7) Timbangan. 8) Kaca pembesar (lup)/Mikroskop. 9) Alat ukur kualitas air. 10) Alat tulis. Sedangkan bahan yang digunakan dalam penelitian ini adalah : 1)Moina sp yang diperoleh dari alam (kolam) dengan padat penebaran 30 ekor/baskom plastik. 2) Pupuk cair bioton organik 3) Pupuk kandang yang berasal dari kotoran ayam $4 \mathrm{~kg}$. 5) Air sumur yang telah diaerasi selama 24 jam.

Kegiatan yang dilakukan untuk mempersiapkan fasilitas penelitian terdiri 
dari beberapa tahapan yaitu :

1. Mempersiapkan media pemeliharaan berupa baskom yang sudah dicuci bersih dan dikeringkan di bawah sinar matahari.

2. Mula-mula kita ambil $4 \mathrm{~kg}$ kotoran ayam kering dan kita larutkan ke dalam 401 air sumur larutan kotoran itu kita rendam dulu selama 2 hari dan diberi aerasi.

3. Air larutan pupuk kandang yang telah diaduk dan disaring dengan menggunakan kain strimen sebanyak 31 dimasukkan ke dalam masing- masing baskom.

4. Pupuk cair bioton dimasukkan ke dalam masing-masing baskom sesuai dengan dosis perlakuan dan ulangan.

5. Setelah tiga hari maka terjadi perubahan warna air menjadi kecoklatan karena ditumbuhi oleh phytoplankton yang nantinya menjadi pakan utama Moina sp., lalu dimasukan Moina sp. ke dalam media pemeliharaan dengan padat penebaran masing-masing 30 ekor.

Metode yang digunakan dalam penelitian ini adalah metode eksperimen yaitu suatu metode yang bertujuan untuk menyelidiki kemungkinan saling hubungan sebab akibat dengan cara mengenakan satu atau lebih kelompok percobaan satu atau lebih kondisi perlakuan dan memperbandingkan hasilnya dengan satu atau lebih kelompok kontrol yang tidak dikenai kondisi perlakuan (Rimalia \& Yulius, 2019).

Perlakuan yang diterapkan sebanyak 4 perlakuan dengan 3 kali ulangan, dengan perlakuan pemberian dosis pupuk cair Bioton sebagai berikut : $\mathrm{A}=5$ $\mathrm{ml} / 31$ air, $\mathrm{B}=10 \mathrm{ml} / 3 \mathrm{l}$ air, $\mathrm{C}=15 \mathrm{ml} / 31$ air, $\mathrm{D}=$ tanpa Pupuk cair Bioton (kontrol).

Pengamatan yang dilakukan adalah melihat kelimpahan Moina sp yang dihasilkan dalam setiap media. Pengambilan contoh kelimpahan Moina sp dilakukan setiap dua hari sekali, yang diambil menggunakan plankton net, kemudian plankton net yang sudah berisi Moina sp diambil menggunakan pipet tetes dan dihitung dengan handy counter. Pengamatan dilakukan selama 8 hari. Selanjutnya untuk pengamatan terhadap parameter kualitas air meliputi a) Suhu air, diukur dengan thermometer tiap pagi dan tiap sore hari. b) Derajat keasaman $\mathrm{pH}$, diukur dua kali pada awal dan akhir penelitian dengan menggunakan $\mathrm{pH}$ meter.

Data yang di dapat mula-mula diuji kenormalannya dengan menggunakan uji kenormalan Lillifor. Kemudian diuji pula kehomogenannya menggunakan uji homogenitas Bartllet. Dilanjutkan uji anova dan apabila hasil uji anova menunjukkan hasil perbedaan yang nyata atau sangat nyata maka dilakukan uji beda nilai tengah perlakuan menggunakan BNT. Untuk mengetahui uji beda nilai tengah, terlebih dahulu perhitungan koefisien keragaman (Harsojuwono, et. al., 2011).

Hipotesis penelitian adalah : $\mathrm{H}_{0}=$ Pemberian pupuk cair Bioton dengan dosis vang berbeda tidak berpengaruh terhadap kelimpahan populasi Moina sp. dan $\mathrm{H}_{1}=$ Pemberian pupuk cair Bioton dengan dosis yang berbeda berpengaruh nyata terhadap kelimpahan populasi Moina sp.

\section{HASIL DAN PEMBAHASAN}

\section{Kelimpahan Populasi Moina sp.}

Kelimpahan dimaksudkan sabagia total jumlah individu yang terdapat dalam media percobaan yang diperoleh dari hasil perhitungan. Pengamatan pada penebaran awal $10 \mathrm{ind} / 1$ media dan hasil pengamatan selama penelitian 8 hari diperoleh kelimpahan Moina sp rata-rata individu per 1 air media dari masing-masing perlakuan dapat dilihat pada Tabel 1. Pada pengamatan terhadap rata-rata jumlah akhir individu, dengan padat penebaran awal masing-masing 10 ind/l perlakuan A (Bioton sebanyak $5 \mathrm{ml} / \mathrm{l}$ ) mempunyai kelimpahan terbesar yaitu sebanyak 1444 Ind/l, sedangkan rata-rata jumlah individu terkecil terjadi pada perlakuan C (Bioton $15 \mathrm{ml} / \mathrm{l}$ ) yaitu sebanyak 900 ind./1 dan untuk lebih jelasnya mengenai jumlah rata-rata individu Moina sp pada masingmasing perlakuan dapat dilihat pada Lampiran 3, 4,5 dan 6. untuk mengetahui rata-rata kelimpahan Moina $\mathrm{sp}$ pada masing-masing perlakuan dapat dilihat pada Gambar 1. 
Tabel 1. Jumlah rata-rata (Ind/l) Moina sp. selama 8 hari pengamatan

\begin{tabular}{ccccc}
\hline \multirow{2}{*}{ Ulangan } & \multicolumn{5}{c}{ Perlakuan } \\
\cline { 2 - 5 } & $\mathrm{A}$ & $\mathrm{B}$ & $\mathrm{C}$ & $\mathrm{D}$ \\
\hline I & 1533 & 1000 & 867 & 1067 \\
\hline II & 1467 & 1100 & 933 & 967 \\
\hline III & 1333 & 1200 & 900 & 1000 \\
\hline Jumlah & 4333 & 3633 & 2700 & 3034 \\
\hline Rata-rata & $1444,33^{\mathrm{a}}$ & $1211^{\mathrm{b}}$ & $900^{\mathrm{c}}$ & $1011^{\mathrm{c}}$ \\
\hline
\end{tabular}

*notasi yang sama menunjukkan tidak berbeda nyata berdasarkan BNT 5\%.

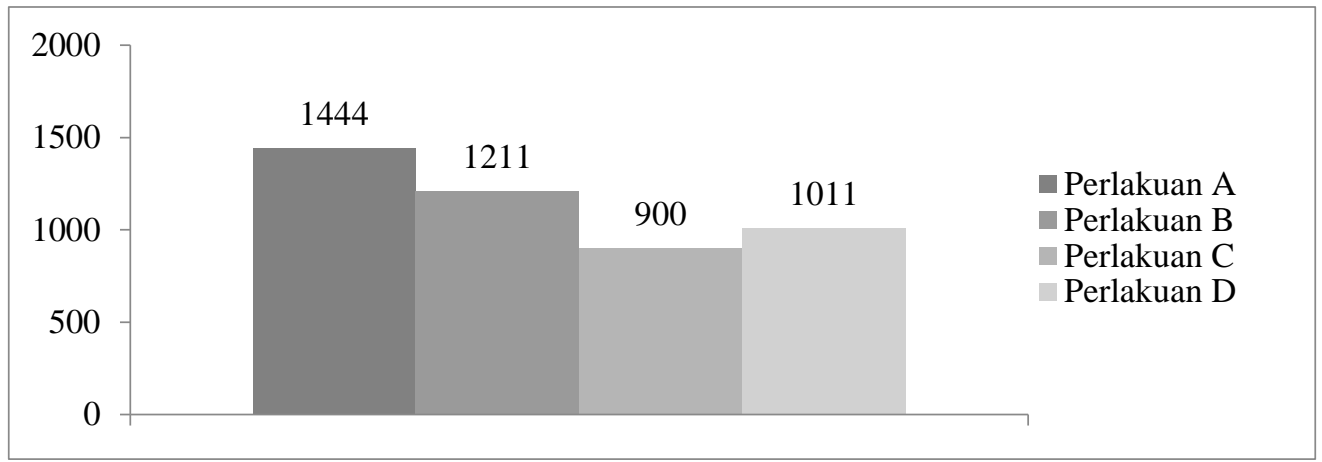

Gambar 1. Grafik Rata-rata Kelimpahan Populasi Moina sp (Ind/L)

Dari kempat perlakuan terlihat memiliki perbedaan tingkat kelimpahan yang nyata, hal ini diakibatkan oleh perbedaan dosis pupuk cair Bioton yang diberikan, semakin banyak dosis yang diberikan semakin berkurang kelimpahannya karena sifat dari bioton sebagai pupuk organik dan perombak, semakin banyak dosis yang diberikan maka $\mathrm{pH}$ semakin meningkat dan dimungkinkan menghambat perkembangbiakan Moina sp. Perlakuan A menunjukan hasil yang terbaik dengan dosis $5 \mathrm{ml} / \mathrm{l}$ yang dapat memberikan pengaruh yang optimal bagi perkembangan Moina sp.

Berdasarkan hasil uji kenormalan menurut Lilliefors, didapat nilai L hitung $(0,1311)<$ L tabei $1 \%(0,275)$ dan L tabel $5 \%(0,242)$, maka data tersebut menyebar normal dan hasil uji Homogenitas ragam menurut Bartlett, diperoleh $X^{2}$ hitung sebesar 3, $97<X^{2}$ tabel $1 \%(5,99)$ dan $X^{2}$ tabel $5 \%(9,21)$, maka ragam data menyebar homogen.

Selanjutnya analisis keragaman (anova) menghasilkan nilai $\mathrm{F}$ hitung sebesar 24,78 > F tabel 5\% (4,07) dan F tabel $1 \%(7,59)$, maka terima hipotesa $\mathrm{Hi}$ diterima dan $\mathrm{H}_{\mathrm{o}}$ di tolak yang artinya pemberian bioton dengan dosis yang berbeda memberikan pengaruh yang sangat nyata terhadap kelimpahan populasi Moina sp yang dipelihara dalam baskom plastik. Kemudian hasil uji Beda Nyata Terkecil (BNT) diperoleh semua perlakuaan berbeda sangat nyata kecuali antara perlakuan D dengan $C$ hanya berbeda nyata. Dengan demikian kelimpahan moina sp dipengaruhi oleh perbedaan dosis Bioton yang diberikan pada media hidup Moina $\mathrm{sp}$, dengan kelimpahn tertinggi pada dosis bioton sebanyak $5 \mathrm{ml} / \mathrm{l}$ mempunyai kelimpahan moina sp terbesar yaitu sebanyak 1444 Ind/l.

\section{Parameter Kualitas Air} Suhu Air $\left({ }^{\circ} \mathbf{C}\right)$

Suhu air pada media penelitian kali ini berada pada kisaran yang sempit dimana suhu terendah adalah $26^{\circ} \mathrm{C}$ dan suhu tertinggi adalah $29^{\circ} \mathrm{C}$. Hasil penelitian (Rosyadi, 2013) suhu air berkisar $25-8^{\circ} \mathrm{C}$ dan (Muhasdika, et al. 2015) dengan suhu air $26-28^{\circ} \mathrm{C}$ sesuai untuk kelangsungan 
hidup moina sp.

\section{pH Air (Derajat Keasaman)}

Hasil pengukuran selama pengamatan rata-rata $\mathrm{pH}$ air harian pada masing-masing perlakuan berkisar antara 6,92 - 7,88. Hasil penelitian Muhasdika, et al. (2015) nilai pH selama kultur artemia adalah 6,0 - 7,0 dan Rosyadi (2013) nilai pH selama kultur artemia adalah $5-8$. Maka nilai $\mathrm{pH}$ selama penelitian ini dapat dikatakan baik.

\section{KESIMPULAN}

Kelimpahan populasi Moina sp terbesar pada perlakuan A (Pemberian Bioton sebanyak $5 \mathrm{ml} / 31$ air) yaitu sebanyak 1444 Ind./l Moina sp. Hasil pengukuran suhu air berada dalam kisaran $26^{\circ} \mathrm{C}-29^{\circ} \mathrm{C}$ dengan data suhu air pagi 26,5 ${ }^{\circ} \mathrm{C}$ dan sore hari $28,6^{\circ} \mathrm{C}$, Hasil $\mathrm{pH}$ harian pada masing-masing perlakuan berkisar antara $6,92-7,88$.

\section{DAFTAR PUSTAKA}

Agus, M., Mardiana, T. Y., \& Bisrul, N. (2010). Pengaruh Perbedaan Jenis Pakan Alami Daphnia, Jentik Nyamuk dan Cacing Sutera terhadap Pertumbuhan Ikan Cupang Hias (Betta splendens) "The Effect of Different Types Of Natural Food Daphnia, Mosquito Larvae and Silk Worms to Growth of Ornamental Fish Bett." Pena Akuatika: Jurnal Ilmiah Perikanan Dan Kelautan, 2(1), 21-29.

Aggraeni, N.M. \& Abdulgani, N. (2013). Pengaruh Pemberian Pakan Alami dan Pakan Buatan Terhadap Pertumbuhan Ikan Betutu (Oxyeleotris marmorata) pada Skala Laboratorium. Jurnal Sains Dan Seni ITS, 2(2), 197-201. https://doi.org/10.12962/j23373520.v 2i2.4067

Asriani, Joko, S. \& Listyarini, S. (2018). Nilai Gizi Konsentrat Protein Ikan Lele Dumbo (Clarias gariepenus)
Ukuran Jumbo. Jurnal Kelautan Dan Perikanan Terapan, 1(2), 77-86. http://ejournalbalitbang.kkp.go.id/ind ex. php/jkpt/article/view/7257

Chilmawati, D. (2008). Penggunaan Media Kultur yang Berbeda terhadap Pertumbuhan Chlorella Sp. Indonesian Journal of Fisheries Science and Technology, 4(1), 42-49. https://doi.org/10.14710/ijfst.4.1.4249.

Harsojuwono, B. A., Arnata, I. W., \& Puspawati, G. A. K. D. (2011). Rancangan Percobaan: Teori, Aplikasi SPSS dan Excel. In LINTASKATA Publishing. https://doi.org/10.1017/CBO9781107 415324.004.

Husma, A. (2017). Biologi Pakan Alami (p. 126). CV.Social Politic Genius (SIGn).

Muhasdika, C., Ro, \& Johan, T. I. (2015). Pemberian Pupuk Bokashi dengan Dosis Berbeda pada Media Air Limbah Rumah Tangga terhadap Perkembangan Populasi Moina sp. Jurnal Dinamika Pertanian, XXX(April), 69-76.

Rimalia, A., \& Yulius, K. (2019). Optimasi Daya Tetas Telur Ikan Gurami (Osphronemus gouramy Lac) dengan Pengontrolan Suhu Air. EnviroScienteae, 15(1), 79-85. https://doi.org/http://dx.doi.org/10.20 527/es.v15i3.7425.

Rosyadi. (2013). Pemberian Pupuk Organik Cair Lengkap (POCL) Super ACI dengan Dosis berbeda terhadap Perkembangbiakan Moina sp. Dinamika Pertanian, XXVIII, 153160.

https://journal.uir.ac.id/index.php/din amikapertanian/article/view/893. 